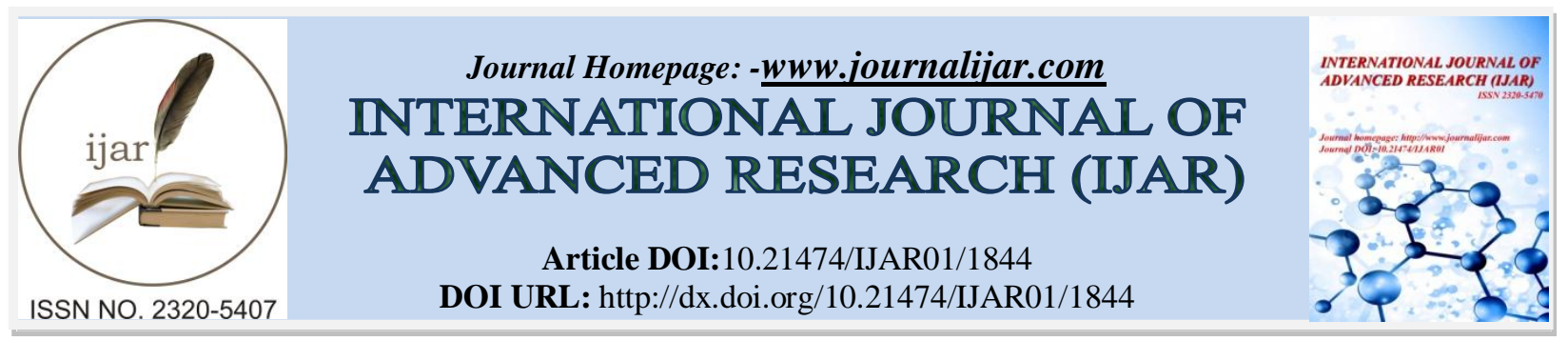

RESEARCH ARTICLE

\title{
VALORIZATION OF CASHEW APPLES FOR BIOETHANOL PRODUCTION BY ALCOHOLIC FERMENTATION.
}

\section{Djossou Andriano Jospin, Mazou Mouaimine, Tchobo Paul Fidele, Boco C. C. Kwame N'krumah O, and Soumanou Mansourou Mohamed.}

Unite de Recherche en Genie Enzymatique et Alimentaire, Laboratoire d'Etude et de Recherche en Chimie Appliquee, Ecole Polytechnique d'Abomey-Calavi, Universite d'Abomey-calavi, 01 BP 2009, Cotonou, Benin.

\section{Manuscript Info}

Manuscript History

Received: 12 August 2016

Final Accepted: 22 September 2016

Published: October 2016

Key words:-

Ethanol, alcoholic fermentation, cashew apple, physicochemical characteristics optimization

\section{Abstract}

In this research we followed the process of fermentation by measuring the physicochemical parameters. The alcoholic fermentation of the cashew apple must in the palm wine is described in three phases. In the first five days we notice a significant consumption of glucose in which there is a drops of the total soluble solid content and $\mathrm{pH}$. During the second phase, (from the sixth to tenth day), there is allowed consumption of glucose and ethanol production. From the eleventh to the fifteenth day the fermentation remain stable. Optimizing the efficiency of ethanol production was made by using the response surface methodology. The rate of ferment, the fermentation time, and the distillation time are the selected factors at three levels for the realization of the Box Benhken plan. The collected data are subject to an analysis of variance (ANOVA) and are modeled by a polynomial equation of the second order with interaction (linear, quadratic) of order two. The maximum return is $11.35 \%(\mathrm{~m} / \mathrm{m})$ and the optimum conditions for this performance are: rate $0.79 \%$, fermentation time 4.7 days, and distillation time $113.15 \mathrm{~min}$.

Copy Right, IJAR, 2016,. All rights reserved.

\section{Introduction:-}

Like several African countries of south in the Sahara, Benin has a predominantly agricultural economy. Among the more or less structured agricultural sectors which are actively involved in the economic life we have the cotton sector, the oil palm sector, the cassava sector, the cashew sector and the pineapple industry. Fruits and by-products of fruit processing industry are produced annually in large quantities all over the world (Grigoras 2012). Unfortunately in Benin, fruits and by-poducts of fruit processing there are not recycled and are often crammed into wild dumps in the vicinity of processing centers (Aboh et al., 2008). Cashew for Benin, is an interesting alternative which is economically the second agricultural export product of the country behind cotton (Aivodji 2009). Cashew has emerged as a strategic culture whose development prospects and income guarantee for a sustainable diversification of farms are very promising (Tandjiekpon 2005). If the raw material instead of being transformed after harvest is sold in rough it is clear that there will be no by product which will yield any profit. Yet, these could be an important source of income if a good strategy takes place. The production of bioethanol is for example a good opportunity.

Corresponding Author:-Djossou Andriano Jospin.

Address:- Unite de Recherche en Genie Enzymatique et Alimentaire, Laboratoire d'Etude et de Recherche en Chimie Appliquee, Ecole Polytechnique d'Abomey-Calavi, Universite d'Abomey-calavi, 01 BP 2009, Cotonou, Benin. 
A part from the kernel the other by-products of cashew nut are not valued. The cashew apple is considered as a waste in the cashew industry; it is rot in the fields (Mohanty et al., 2006; Santos 2007). It has astringent component that give an unpleasant feeling to its consumption, which limited its use on the global juice market (Couture 1993). Scale processing of apple juice or alcohol is still embryonic Gnimadji 2008). That's why Karuppaiya et al., (2010), face to this under exploitation, said that the cashew aplle has no commercial value except for countryman who use it for their local alcoholic beverage production (Kruppaiya et al., 2009). Owing to the profit they draw from it, some people grant more credit to the cashew nut than cashew apple (Gilleo et al., 2011). The main objective of our work is to produce alcohol from the cashew apple. This work aims to develop the agricultural and agro-industrial byproducts

\section{Material and Methods:-}

\section{Vegetable material:-}

The cashew apples we used have been harvested in save a city in the center of Benin. Two varieties of apple, both grow in Benin (yellowish and reddish skin). The palm wine (Elaeisguineensis Jacq) we used as a ferment, was purchased at a farmer's in the city of Allada.

\section{Methods:-}

\section{Study of the kinetics of the fermentation:-}

The cashew apples after due cleaning were cut into four (4) or six (6) parts. They were manually pressed and filtered with a muslin cloth to collect the filtrate which will serve as mash for the fermentation. In a 5 liter container, $400 \mathrm{~g}$ of the obtained has been poured. To the content of each of each container we added $4 \mathrm{~g}$ of ferment which equals $1 \%$ of the mass of the cashew juice. Within the context of fermentation kinetics study, four series have been simultaneously performed at the surrounding temperature (about $30^{\circ} \mathrm{C}$ ) with the cashew apple mash. Data were recorded on the fifth, tenth and fifteenth days. In order to avoid the formation of large particles in the mash to ferment, which will reduce the yeast activity, the content is manually stirred every day. We use a still column system to perform the distillation.

\section{Experimental design:-}

A 3-level-3-factor (factorial) plan has been used in this research requiring 15 experiments with the Box Behnken plan. The variables and their selected levels for the fermentation optimization were: ferment proportion $(0-1 \%)$, fermentation time (0-5 days) and distillation time (10-120 minutes). Table 1 shows the independent factors (x ), levels and experimental design in terms of coded $(0,1$, and -1$)$ and uncoded (actual value). To avoid bias, the fifteen experiments have been performed in a totally randomly.

Table 1:- Experimental design and answers obtained.

\begin{tabular}{|c|c|c|c|c|c|}
\hline \multirow{2}{*}{$\mathrm{N}^{\circ}$} & \multicolumn{3}{|c|}{ Factor } & \multirow{2}{*}{ Yield of distillation $\mathrm{Y}(\%)$} & $\ln (\mathrm{Y})$ \\
\cline { 2 - 4 } & $\mathrm{X}$ & $\mathrm{Y}$ & $\mathrm{Z}$ & & 0.15079 \\
\hline 1 & $1(1)$ & $1(2.5)$ & $0(10)$ & 1.16275 & -0.48329 \\
\hline 2 & $1(0)$ & $-1(5)$ & $0(65)$ & 0.61675 & 0.32172 \\
\hline 3 & $-1(0.5)$ & $1(2.5)$ & $0(65)$ & 1.3795 & 0.15892 \\
\hline 4 & $-1(0.5)$ & $-1(5)$ & $0(10)$ & 1.17225 & 0.32226 \\
\hline 5 & $1(0.5)$ & $0(2.5)$ & $1(65)$ & 1.38025 & 0.74610 \\
\hline 6 & $1(1)$ & $0(2.5)$ & $-1(120)$ & 2.10875 & -1.33750 \\
\hline 7 & $-1(0.5)$ & $0(0)$ & $1(10)$ & 0.2625 & 1.64534 \\
\hline 8 & $-1(1)$ & $0(5)$ & $-1(65)$ & 5.18275 & -1.30012 \\
\hline 9 & $0(0)$ & $1(2.5)$ & $1(120)$ & 0.2725 & 0.24803 \\
\hline 10 & $0(0.5)$ & $1(2.5)$ & $-1(65)$ & 1.2815 & -0.24526 \\
\hline 11 & $0(0.5)$ & $-1(0)$ & 120 & 0.7825 & -0.27938 \\
\hline 12 & $0(0)$ & $-1(0)$ & $-1(65)$ & 0.75625 & 1.53977 \\
\hline 13 & $0(0.5)$ & $0(5)$ & $0(120)$ & 4.6635 & -1.54881 \\
\hline 14 & $0(0)$ & $0(2.5)$ & $0(10)$ & 0.2125 & -0.25360 \\
\hline 15 & $0(1)$ & $0(0)$ & $0(65)$ & 0.776 & \\
\hline
\end{tabular}

$\mathrm{Y}$ : yield of distillation; $\mathrm{N}^{\circ}$ were run in a totally random order. ; a: ferment proportion; b: fermentation time; c: distillation time; Numbers in parenthesis represent actual experimental amounts. 


\section{Physicochemical analysis:-}

The $\mathrm{pH}$ of the various juice samples were measured directly in duplicate with $10 \mathrm{ml}$ of each sample using a $\mathrm{pH}$ meter (waterproof $0.00-14.00 \pm 0,05 \mathrm{pH}$ ) calibrated with $\mathrm{pH} 4$ buffer solutions $\mathrm{pH} 7$ at $25^{\circ} \mathrm{C}$. The soluble solids content of the wort $\left({ }^{\circ}\right.$ Brix $)$ were measured in using a refractometer zuzi $(0-32 \% \pm 0.2 \%)$

The total titratable acidity was determined by the dosage of $5 \mathrm{ml}$ of each sample with a standardized solution of sodium hydroxide $\mathrm{NaOH}(\mathrm{pH} 8.3)$ at a concentration $0.05 \mathrm{~N}$, in the presence of a colored indicator, phenolphthalein $1 \%$ according to the OIV-MA-AS313-02 method. The turning of the indicator is marked by the appearance of the pink color. Acidity, expressed as citric acid percentage was then calculated.

$\%$ Citric acid $=\left(\mathrm{C}_{\mathrm{NaOH}} \times \mathrm{V}_{\mathrm{KOH}} \times \mathrm{M}_{\text {acide citrique }} \times 100\right) /\left(5 \times \rho_{\text {aliquote }}\right)$ so: $\%$ Citric acid $=192 \times(\mathrm{VKOH} /$ paliquote $)$

The density at $20^{\circ} \mathrm{C}$ was determined on the samples of wine and distillates by pycnometry according to OIV-MAAS2-01A method. The volumialalcoholometric title (TAV) by sample has been calculated with the help of the results obtained from the ethanol dosage by Cordebardnitrochromique method.

\section{Statistical analysis:-}

The experimental data (Table 1) were analyzed by the response surface regression procedure (RSREG) to fit the following second-order polynomial equation:

$$
Y=a_{0}+\sum_{i=1}^{3} a_{i} X_{i}+\sum_{i=1}^{3} a_{i i} X_{i}^{2}+\sum_{i=1}^{2} \sum_{j=i+1}^{3} a_{i j} X_{i} X_{j}+e_{k}
$$

Where $\mathrm{Y}$ is the response (distillation yield \%); ai, aii and aij are constant coefficients; and $\mathrm{Xi}$ and $\mathrm{Xj}$ are uncoded independent variables.

\section{Result and discussion:-}

Kinetic study of fermentation process of cashew apple wine:-

In this investigation, we demonstrated the production of high ethanol concentration by using cashew apples forsaken by the trader of cashew nut. Figures 1, 2 and 3 show the evolution of the parameters kinetics (Brix degree, pH, TAV and the yield) of distillation during fifteen day of fermentation for cashew apple must pasteurized without ferment, pasteurized without ferment and pasteurized with ferment.Brix degree and $\mathrm{pH}$ are represented on the main axis; TAV and distillation yield on the secondary axis.

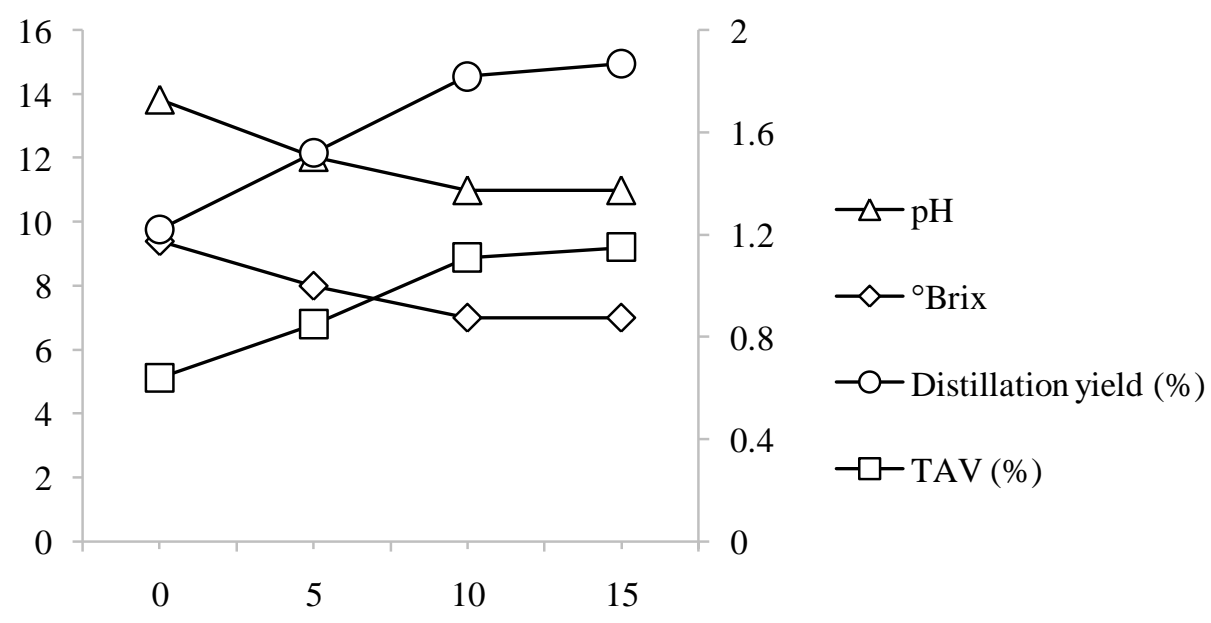

Figure 1:- Variation of ${ }^{\circ} \mathrm{Brix}, \mathrm{pH}, \mathrm{TAV}(\%)$ and yield of distillation (Y (\%)) according to time (days) for the cashewapples wine sample not pasteurized without ferment addition. 


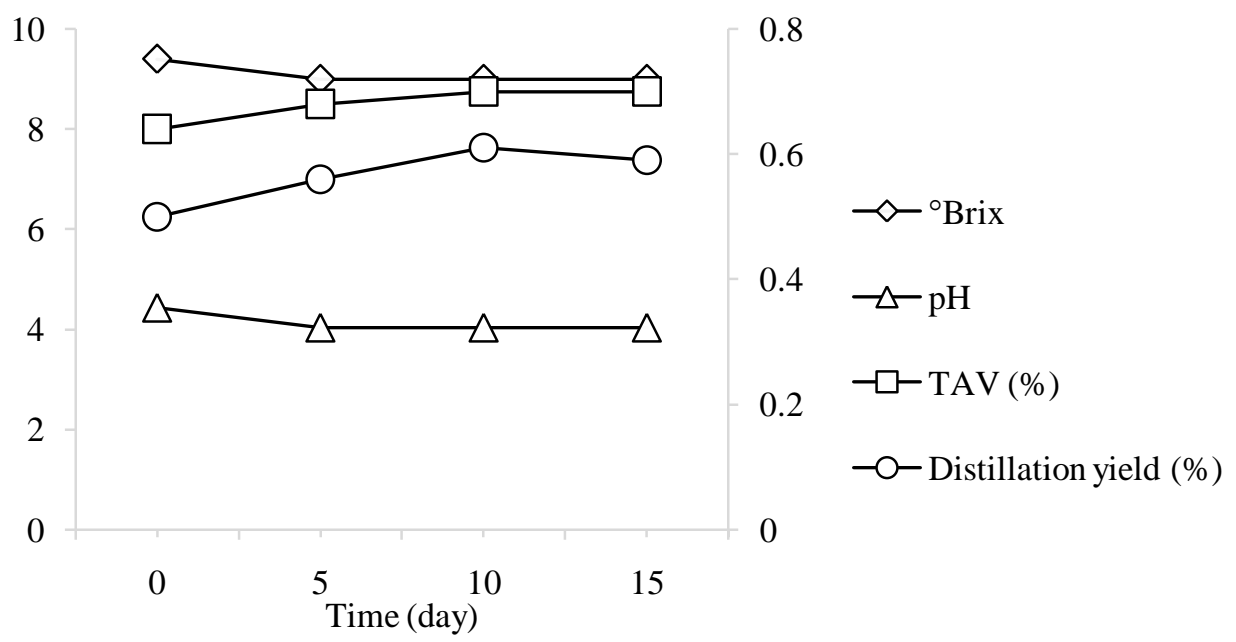

Figure 2:- Variation of ${ }^{\circ} \mathrm{Brix}, \mathrm{pH}, \mathrm{TAV}(\%)$ and yield of distillation $(\mathrm{Y}(\%))$ according to time (days) for the cashew apples wine sample pasteurized without ferment addition.

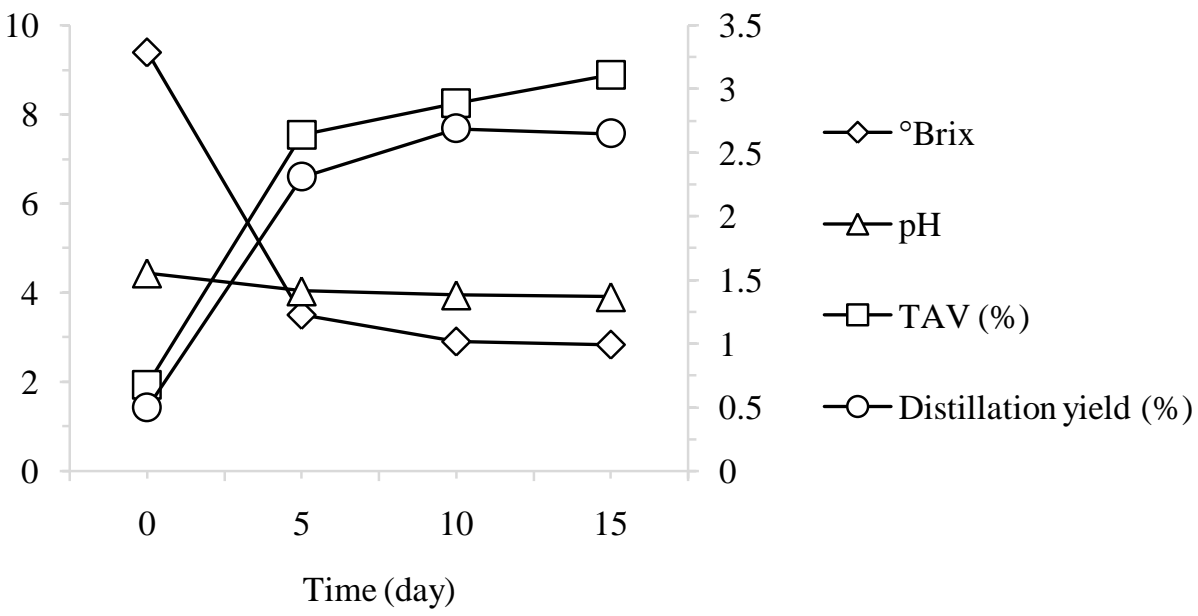

Figure 3:- Variation of ${ }^{\circ} \mathrm{Brix}, \mathrm{pH}, \mathrm{TAV}(\%)$ and yield of distillation $(\mathrm{Y}(\%))$ according to time (days) for the cashew apples wine sample pasteurized with ferment addition.

The analysis of figure 1 shows that the Brix degree, the $\mathrm{pH}$, the TAV and the distillation yield varies respectively from 9.4 to $7,4.44$ to $4.00,0.64$ to $1.15 \%$ (v/v) and 0.58 to $0.72 \%$. This variation would be due to the action of the initial microbial flora of the cashew apple must. After pasteurization of must we do not observe significant variation of these various parameters kinetics according to the time of fermentation (figure 2).

About the figure 3, the variations of the kinetic parameters observed in the course of time is in concordance with the kinetics of growth of yeasts in particular an acceleration phase, a stationary phase and a deceleration. The variation of the Brix degree shows that the activity of yeasts can be to slip into three phases. The first goes from the first to fifth day corresponds to an intense activity of the yeasts ( 9.4 to $3.5^{\circ}$ Brix) that is to say a reduction of 5.9 Brix. The second phase of the sixth at the tenth day shows a drop of the yeasts activity of. The last phase of eleventh at the fifteenth day corresponds to a reduction of 0.07 Brix. The $\mathrm{pH}$ of the must of cashew apples have decreased gradually until the 15th day of fermentation. According to Akin (2008) (Akin 2008). The decrease of the pH corresponds to the consumption of the fermentable sources of sugars.

The evolution of the voluminalalcoholometric title of the must of cashew apple depends on the fermentation period. We notice an increase in the TAV according to the phase of microbial growth. This content is $2.64(\mathrm{v} / \mathrm{v}), 2.89(\mathrm{v} / \mathrm{v})$ and $3.27(\mathrm{v} / \mathrm{v})$ respectively in musts cashew apple of the fifth, tenth and fifteenth day. The TAV is on average $0.68 \%$ 
$(\mathrm{v} / \mathrm{v})$ at first of fermentation. It is thus to notice that significant increase of TAV in the must cashew apples of first at the fifth fermentation day; that is to say approximately $2 \%(\mathrm{v} / \mathrm{v})$. The study of the evolution of the soluble solid content (Brix) shows a significant consumption of sugar (about $5.9^{\circ} \mathrm{Brix}$ ). In relation to the results of TAV, we can say that the yeast also uses glucose as source of energy.

\section{Model fitting:-}

The methods of statistical analysis is based on the data normality assumption. Normality Kolmogorov-Smirnov test is significant for $\mathrm{p}$-value $<0.05$. The normality assumption is thus not compatible with our data on the fermentation yield. We have therefore converted the dependent variable in order to have a new variable that allows a better description of the examined phenomenon.

In the case of our dependent variable, we have a strong asymmetry to the right of distribution. Thus the transformation suggested is that of the logarithmic curve neperian in order to accentuate the impact of the differences in values on the left side of the distribution, where are grouped the majority of observations.This transformation also reduces the impact of the differences in values on the right side of distribution, where one meets observations very few and far away from the majority values. It shows an improvement in the normality of the distribution. This is confirmed by the test of Kolmogorov-Smirnov ( $p>0.05$ ), which lets reject the assumption of not-normality.

The procedure for RSREG Statisticawas employed to fit the second-order polynomial to the experimental data, as Represented distillation yield (Table 1). From the output of RSREG, the second-order polynomial is:

$\ln (Y)=0.297+0.737 x+0.622 y+0.414 z-0.328 x 2+0.188 y 2-0.457 z 2+0.526 x y+0.086 x z+0.072 y z$

With : $x$ rate of ferment; $y$ fermentation time and $\mathrm{z}$ distillation time.

The analysis of variance from Table 2 (ANOVA) indicated that the second-order polynomial model was statistically significant and adequate to represent the actual relationship between the response (distillation yield) and the significant variables, with very small $p$-value (0.002) and satisfactory coefficient of determination $\left(R^{2}=0.992\right)$.

Table 2:- ANOVA for immobilization variables pertaining to the response distillation yield.

\begin{tabular}{|c|c|c|c|}
\hline Source & Degrees of freedom & Sum of squares & $\begin{array}{c}\text { Probability } \\
(\mathrm{P}<0.05)\end{array}$ \\
\hline Model & 9 & 11.2925 & 0.002 \\
\hline Linear & 3 & 8.8226 & 0.006 \\
\hline Square & 3 & 1.3135 & 0.199 \\
\hline Interaction & 3 & 1.1564 & 0.233 \\
\hline Lack-of-Fit & 3 & 0.9629 & 0.006 \\
\hline Pure error & 2 & 0.0036 & \\
\hline Total error & 14 & 12.2591 & \\
\hline
\end{tabular}

Figures 4, 5 and 6 presents the Iso-response curve adjusted of the yield neperian logarithm according to the factors. The curves Iso-answers show the variations of the output of distillation according to the parameters two to two. They present also the equations of the second order which translate the effect of these parameters on the answer. The linear terms of the parameters as their interaction have a positive influence on the answer. Thus simultaneous increase in the two parameters involves respectively a variation of the output of distillation from 0.5 to $2.5 \%$; 0 to 0.5 ; 0 to 1.5 and 0.5 to 2.5 respectively for figures $4,5,6,7$.

The function of desirability of the software was used to determine the optimum conditions for the process. The value of the output of distillation (11.37\%) is estimated for 4.7 days of fermentation time for 113.15 minutes distillation with $0.79 \%$ of proportion close to add to the cashew apple pasteurized wine. The alcohol obtained under these conditions has a TAV of 58.55\%. After a second distillation we obtained a product with a TAV of $90.5 \%$ 


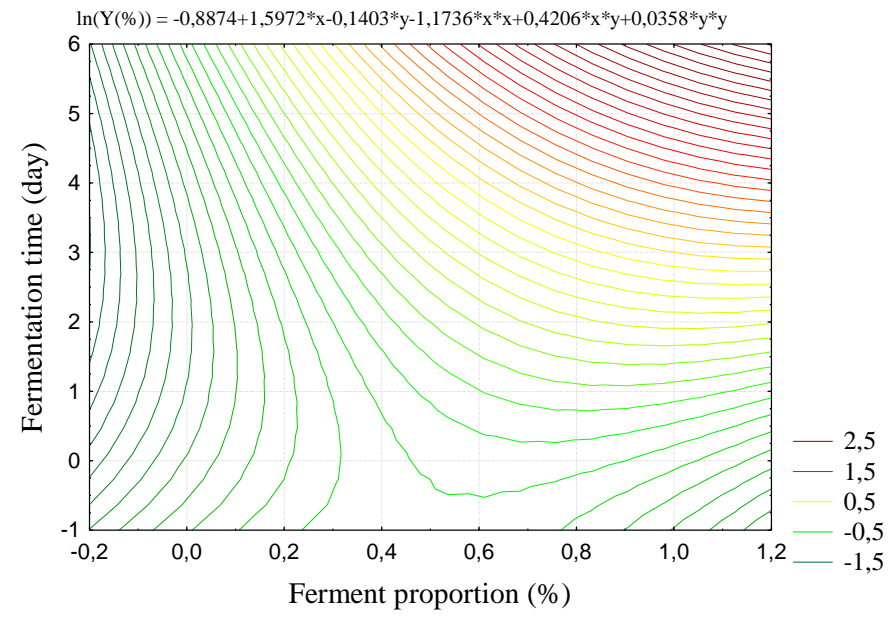

Figure 4:- Iso-response curve showing the variation of $\mathrm{Y}(\%)$ in function of fermentation time and ferment proportion.

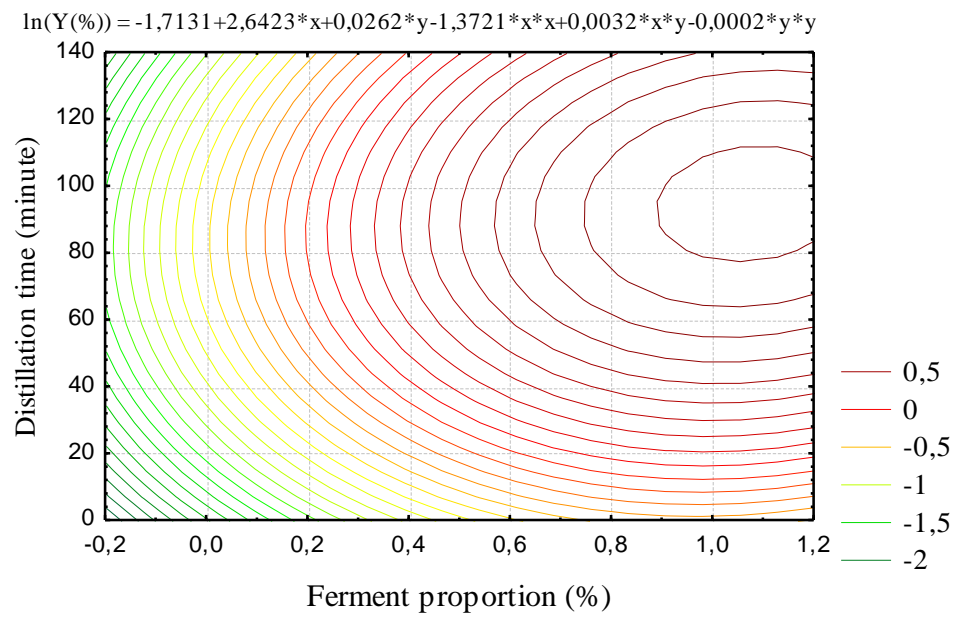

Figure. 5:-Iso-response curve showing the variation of $\mathrm{Y}(\%)$ in function of distillation time and ferment proportion.

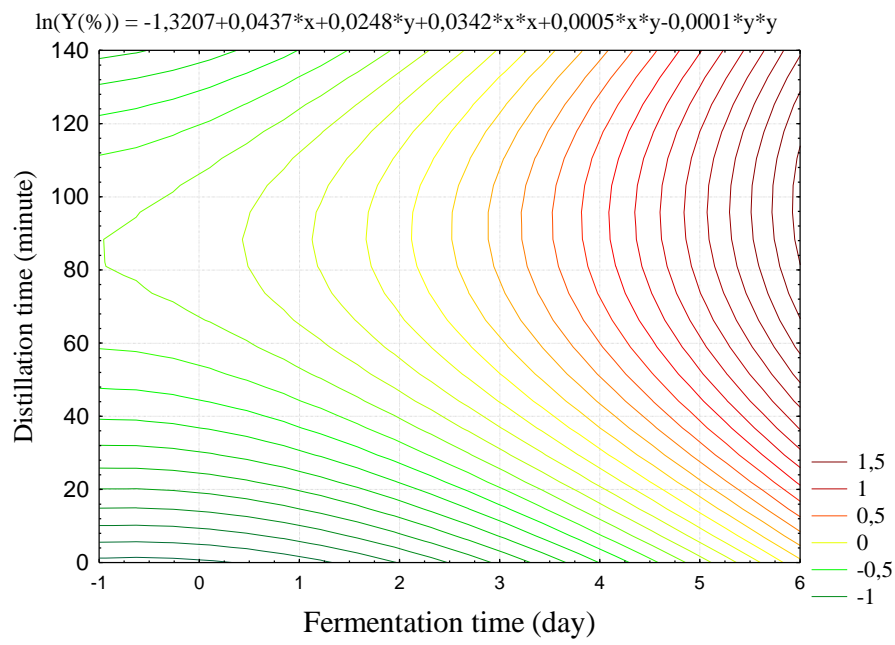

Figure 6:-Iso-response curve showing the variation of $Y(\%)$ in function of distillation time and ferment time 


\section{Conclusion:-}

The objective of this work is to contribute to valorization the apple of cashew tree by the production of bioethanol. To do so, the strategy is to optimize the efficiency of ethanol fermentation from the wort of cashew apple in the methodology of response surfaces. In the first part of the work, we studied the evolution of physico-chemical parameters such as alcohol content by volume (TAV), titratable acidity, Brix, potential-hydrogen each, depending on the duration of fermentation. The results obtained are as follows. The second part of this work is focused on the basis of a Box Benhken plane consisting of 15 trials, implemented methodology of response surfaces which has enabled us to maximize the efficiency of the fermentation cashew wine $11.35 \%(\mathrm{~m} / \mathrm{m})$ and to determine the optimal conditions for this performance which are closed to rate of $0.79 \%$ fermentation time (4.7 days) and distillation time (113.15 $\mathrm{min})$.

\section{Acknowledgement}

This publication was prepared with the assistance of PRONOVABIO and AUF. The African Union and the European Union were gratefully acknowledged.

\section{References:-}

1. Grigoras $\mathbf{C}$ (2012). Valorisation des fruits et des sous-produits de l'industrie de transformation des fruits par extraction des composes bioactifs. Thèse de doctorat de l'Université d'Orléans et de l'Université « Vasilealecsandri » de Bacău.

2. Aboh AB, Ehouinsou MA, Olaafa M et Brun A (2008). Complémentation alimentaire des ovins Djallonké avec les sous-produits de transformation d'ananas : potentiel nutritif, préférence et développement pondéral. Bulletin de la Recherche Agronomique du Bénin. 2008 ; 61:25-30.

3. Aïvodji J Anasside A (2009). Elaboration des règles de stabilisation et de soutien des prix pour la filière anacarde. ONS, Projet d'Appui à la Sécurisation des Revenus des Exploitants Agricoles (PASREA).

4. Tandjiekpon A. Mieux produire l'anacardier au Bénin : Référentiel technico-économique. INRAB; 2005.

5. Mohanty S, Ray P, Swain M, ray R(2006). Fermentation of cashew (Anacardiumoccidentale 1.) "apple" into wine. Journal of Food Processing and Preservation. 30: 314-322.

6. Santos RP. Production and characterization of the cashew (Anacardiumoccidentale L.) peduncle bagasse ashes(2007). Journal of Food Engineering. 79(4):1432-1437.

7. Couture(1993). Valorisation de la pomme de cajou au Vietnam. Rapport final du projet de recherche.

8. Gnimadi A (2008). Etude pour l'identification des filières agroindustrielles prioritaires. Programme de Restructuration et de Mise à Niveau de l'Industrie des Etats membres de l'UEMOA (PRMN).

9. Karuppaiya M, Sasikumar E, Viruthagiri T, Vijayagopal V (2009). Optimization of process parameters using Response Surface Methodology (RSM) for ethanol production from waste cashew apple juice using Zymomonasmobilis. Chemical Engineering Communications. $196: 1433-1443$.

10. Gilleo J, Jassey K, Sallah JAY (2011). Les bases de la filière cajou : Projet d'amélioration de la chaîne de valeurs du cajou dans le Bassin du fleuve Gambie (CEP). IRD.

11. Akin H (2008). Evolution du $\mathrm{pH}$ pendant la fermentation alcoolique de moûts de raisins: modélisation et interprétation métabolique. Doctorat de l'Institut National Polytechnique de Toulouse. 